\title{
Biopterin derivatives in human body fluids and tissues
}

\author{
R. J. LEEMING, J. A. BLAIR, V. MELIKIAN, AND D. J. O'GORMAN ${ }^{1}$ \\ From the General Hospital, Birmingham, the Department of Chemistry, University of Aston in \\ Birmingham, and Dudley Road Hospital, Birmingham
}

SYNOPSIS Levels of biopterin derivatives in urine, serum, milk, cerebrospinal fluid, brain, and liveiehave been measured with the Crithidia fasciculata assay. Normal levels in serum and urine hav $\$$ been given and compared with those in a number of benign and malignant proliferative disorders $s_{0}^{+}$ phenylketonuria, kidney disease, Parkinson's disease, schizophrenia, controlled epilepsy, rheumatoid arthritis, and pernicious anaemia.

The active component of Crithidia factor in serum was 7,8-dihydrobiopterin. Tissue, urine, and some serum samples contained two active materials, the principal one being 7,8-dihydrobiopterin: a minor constituent was probably tetrahydrobiopterin.

Serum biopterin levels following methotrexate administration were raised and subsequent adminie stration of folic acid and 5-formyltetrahydrofolic acid further increased serum levels of biopterip derivatives; this was in contrast to the total absence of response to oral folates without prior metho trexate and to 5-methyltetrahydrofolic acid either with or without methotrexate being given.

Tetrahydrobiopterin is the cofactor in the enzymatic hydroxylation of phenylalanine to tyrosine (Kaufman, 1963) and the further hydroxylation of tyrosine to dopa which limits the rate of catecholamine biosynthesis (Levitt et al, 1965). Hosoda and Glick (1966) gave an additional role for tetrahydrobiopterin in the hydroxylation of tryptophan to 5-hydroxytryptophan. Biopterin (1) and its biologically active reduced derivatives 7,8-dihydrobiopterin (2) and 5,6,7,8-tetrahydrobiopterin (3) differ from folic acid (4) in the substituent at C6 of the pteridine ring. In the rat, biopterin has been shown to be excreted in the absence of dietary biopterin (Pabst and Rembold, 1966).

Raised levels of biopterin derivatives have been reported in the blood of patients with gout (Baker et al, 1961) and in gout, uraemia, and alcoholic liver disease (Baker et al, 1974). Biopterin derivatives have been measured in human brain, liver, and cerebrospinal fluid (Baker et al, 1974).

Fukushima and Shiota (1972) showed that large oral doses of folic acid did not affect urinary levels of biopterin derivatives.

${ }^{1}$ Present address: Regional Hospital, Newcastle, Galway Received for publication 11 November 1975
(1)<smiles>CC(O)C(O)c1cnc2nn[nH]c(=O)c2n1</smiles>

(2)<smiles>CC(O)C(O)C1=Nc2c(nn[nH]c2=O)NC1</smiles>

(3)<smiles>CC(O)C(O)C1Nc2c(nn[nH]c2=O)NC1CNCc1cnc2nn[nH]c(=O)c2n1</smiles> 
In an earlier paper (Leeming and Blair, 1974), methods for the assay and identification of biopterin derivatives in urine were given. This paper now reports a detailed survey of the levels of biopterin derivatives in normal human body fluids and tissues and in various disease states. A well-defined set of conditions under which serum biopterin levels are increased by oral administration of folates and related compounds is also described.

\section{Material and Methods}

\section{MATERIAL}

Biopterin was a gift from Roche Products Ltd. Pteroic acid was a gift from Professor I. H. Rosenberg. 5-Formyltetrahydrofolic acid was a gift from Lederle Laboratories Ltd. The calcium salt of 5-methyltetrahydrofolic acid was prepared by the method of Blair and Saunders (1970). 5-Methyl-5,6dihydrofolic acid was prepared by dissolving $400 \mathrm{mg}$ of 5-methyltetrahydrofolic acid in $200 \mathrm{ml}$ of distilled water containing $5 \mathrm{mg}$ of copper sulphate (Blair et al, 1975). The mixture was stirred under a slow stream of oxygen for 60 to 100 minutes, and the reaction was timed by testing for ultraviolet absorption maxima at $248 \mathrm{~nm}$ and $280 \mathrm{~nm}$ at $\mathrm{pH} 7.0$ in $0.1 \mathrm{M}$ phosphate buffer. Further purification was carried out according to Gapski et al (1971). 5-Methyl-5,8dihydrofolic acid was prepared by dissolving $10 \mathrm{mg}$ of 5-methyl-5,6-dihydrofolic acid in 0.01 M hydrochloric acid 30 minutes before administration. Neutralization with dilute sodium hydroxide immediately preceded use. 7,8-Dihydrofolic acid was prepared according to the method of Futterman (1963). 10-Formylfolic acid was prepared by the method of Blakley (1959). Folic acid (Kodak Ltd) and methotrexate (Lederle Laboratories Ltd) were commercial products.

\section{SUBJECTS STUDIED}

The normal sera were taken from 42 males and 72 females aged 18 to 60 years. The normal urines were from 30 males and 30 females within the same age group. Patients with kidney disease and schizophrenia were inpatients; the remainder were mostly outpatients.

Cerebrospinal fluids were those submitted for routine analysis and which subsequently appeared normal. Expressed breast milk was obtained from normal females within one week of parturition. All samples were taken randomly during the day from non-fasting subjects. Liver and brain were obtained post mortem.

\section{DRUGS}

Children with leukaemia had been receiving be- tween $5 \mathrm{mg}$ and $7.5 \mathrm{mg}$ methotrexate daily for five days. Psoriatics on azothioprine were taking $50 \mathrm{mg}$ once a day, and psoriatics on methotrexate had had from $5 \mathrm{mg}$ to $25 \mathrm{mg}$ orally or parenterally from one to six days before sampling. Patients on Septrin were taking $960 \mathrm{mg}$ twice daily. The schizophrenics were having multiple treatment from a wide selection of drugs. The controlled epileptics were having various doses of phenytoin and phenobarbitone. Patients with Parkinson's disease were, with one exception, taking L-dopa.

\section{PREPARATION OF SAMPLES}

Serum samples were frozen until the day of the test, diluted $1: 20$ with $0.2 \mathrm{M}$ phosphate buffer $\mathrm{pH} 5.0$, autoclaved at $115^{\circ} \mathrm{C}$ for 3 minutes, and centrifuged. The clear supernatant was added in $0.5 \mathrm{ml}$ quantities to three tubes and then treated in a similar way to the standards. Whole blood anticoagulated with dipotassium EDTA was assayed in the same way as serum; where necessary, further $1: 5$ dilutions of extracts were made in buffer. Urine samples were diluted $1: 1000$ in buffer from which three further $1: 5$ dilutions were made. Assays were then carried out as for sera.

Cerebrospinal fluids (CSF) were diluted as sera but not autoclaved. Tissue was homogenized at $50 \mathrm{mg} / \mathrm{ml}$, autoclaved, and assayed as serum. Some samples of tissue were lyophilized to compare the weights of fresh and dehydrated material. Human milk was defatted by centrifugation (Ford, 1974) and then treated as serum. Duplicate samples of milk were filtered through $8 / 32$ inch Visking tubing and the filtrates were assayed.

\section{CHROMATOGRAPHY}

Serum, urine, and tissue extracts were chromatographed on cellulose thin layer plates to $15 \mathrm{~cm}$ in $0.5 \%$ sodium carbonate, $5 \%$ acetic acid, and $3 \%$ ammonium chloride. Eluates were assayed for Crithidia active materials.

\section{FOLATES AND ANTIFOLATES}

Fourteen patients with psoriasis, who had had methotrexate within the previous six days, had serum Crithidia factor levels measured. These were compared with nine psoriatics without systemic therapy, four psoriatics on azothioprine, 12 children with leukaemia who had had methotrexate from 1 to 14 days before sampling, three patients on Septrin (trimethoprim with sulphamethoxazole) and normals.

Blood samples were taken at $0,1,2,3$, and 6 days from a patient who had received a single $25 \mathrm{mg}$ dose of methotrexate intravenously for extensive erythrodermic psoriasis, and at $0,1,2,3,4$, and 24 hours 
from two other psoriatics with severe lesions who had had $5 \mathrm{mg}$ of methotrexate orally. Nine patients had a single $10 \mathrm{mg}$ dose of methotrexate orally followed 24 hours later by different pteridines. Two of these had $5 \mathrm{mg}$ of oral folic acid, two had $10 \mathrm{mg}$ of 5-methyltetrahydrofolic acid orally, two had $10 \mathrm{mg}$ of 5-formyltetrahydrofolic acid orally, two had $5 \mathrm{mg}$ of 5-formyltetrahydrofolic acid intravenously, and one had $5 \mathrm{mg}$ of biopterin orally. Blood samples were taken before the methotrexate was given, immediately before the pteridine, and at $1,2,3,4$, and 24 hours after the pteridine for Crithidia factor assay.

Blood samples were taken for up to 3 hours from normal subjects who had taken oral folates.

\section{MICROBIOLOGICAL ASSAY}

The culture medium for Crithidia fasciculata was that described by Guttman and Wallace (1964), with the addition of $1 \%$ casamino acids (Iwai et al, 1970). Experiments showed that casamino acids produced a considerable increase in maximum growth, and it was not necessary to pretreat with charcoal. The medium was prepared without vitamins, haemin or triethanolamine at 10 fold concentration, steamed for 20 minutes, and stored in screwcapped bottles at $4^{\circ} \mathrm{C}$. The vitamins were prepared as a dry mix, with the exception of folic acid which was added from a stock kept for folic acid assays. The complete double-strength medium was adjusted to $\mathrm{pH} 7 \cdot 5$. The addition of buffered biological material or standard produced a final $\mathrm{pH}$ of $6 \cdot 5$. This optimum $\mathrm{pH}$ value was arrived at independently by Baker et al (1974).

The standard (in triplicate) was prepared by adding $0,10,20,30,40,50,60,70,80,90,100$, and $150 \mathrm{pg}$ of biopterin/tube in $0.5 \mathrm{ml}$ quantities of $0.2 \mathrm{M}$ phosphate buffer $\mathrm{pH} 5.0$. The volume was made to $4.0 \mathrm{ml}$ by adding $1.5 \mathrm{ml}$ distilled water and $2.0 \mathrm{ml}$ double-strength medium.

The inoculum was prepared by taking one drop of a two-day culture in maintenance medium (Leeming and Blair, 1974) and adding it to $15 \mathrm{ml}$ single-strength medium, incubating for four days to exhaust endogenous growth factor, and diluting $1: 100$ in single-strength medium; 1 drop was added to each test. Ampicillin, $25 \mathrm{mg} / \mathrm{ml}$, added to this inoculum assisted in preventing bacterial contamination. Incubation was at $29^{\circ} \mathrm{C}$ in the dark for four days. Reading was carried out on a semi-automated system (Leeming and Graham, 1973).

The assay was specific for biopterin, 7,8-dihydrobiopterin, 5,6,7,8-tetrahydrobiopterin, and L-neopterin. Folates and antifolates at the levels described in this paper did not affect the growth of Crithidia fasciculata.
Results

BODY FLUID AND TISSUE LEVELS Mean serum levels of biopterin derivatives in norm卉 subjects and patients with various diseases are givef in table I. Urine levels are given in table II. Norma serum biopterin derivative levels ranged from $0.4 \mathrm{ng} / \mathrm{ml}$ to $3.6 \mathrm{ng} / \mathrm{ml}$ (mean $1.81 \pm 0.06 \mathrm{ng} / \mathrm{m}$ h and normal urine levels from $0.3 \mu \mathrm{g} / \mathrm{ml}$ to $6.9 \mu \mathrm{g} / \mathrm{m}$ ? (mean $2.1 \pm 0.38 \mu \mathrm{g} / \mathrm{ml}$ ).

Biopterin derivatives in other body fluids and tissues are given in table III. CSF levels were clos to serum levels whereas milk and tissues corr tained markedly higher concentrations. Brain varieg considerably in water content, between both sites of sampling and different patients, while liver seemed fairly constant at around $75 \%$.

Crithidia factor levels in solid tissues were verg much higher than those found in serum and CSE (table III), probably resulting from intracellulas biosynthesis. Similar levels in brain and liver have been reported (Baker et al, 1974). Levels in milk were more akin to those found in tissues than in serum, although total folate levels measured by $L$. case $i$ were very similar to those found in seruro $(5.5 \mathrm{ng} / \mathrm{ml} \pm 1.0 \mathrm{ng} / \mathrm{ml})$. The difference betwee Crithidia factor in unfiltered and protein-free mils (table III) was statistically significant $(\mathrm{P}<0.01 \mathrm{~g}$ Folates are also bound to whey proteins (Ford, 1974\%

LEVELS IN DISEASE

Serum values from patients with cirrhosis, Parkin? son's disease, and epilepsy did not show any statist? cally significant variation at the $5 \%$ level by Student $t$ test from the normal group. Those with proliferative disorders were all low although carcinoma patient were not significantly lower (only 6 samples wero tested). Patients with pernicious anaemia, schizos phrenia, rheumatoid arthritis, and regional enteritis all had low serum values. Phenylketonuric and urae mic subjects had significantly raised results. Tho hospital control group of children gave a simila level to normal adults. Urine levels were low in controlled epilepsy but only at the $5 \%$ level of significance by Student's $t$ test. If, however, th\& number of results below $1.0 \mu \mathrm{g} / \mathrm{ml}$ was compareg with the number of normals below this figure the value obtained by applying the $\chi^{2}$ test was more significant $(\mathrm{P}<0.01)$. Urine levels in rheumatoi $\$$ arthritis and kidney dysfunction were significantly low. Schizophrenics gave values which, although raised, were not significantly elevated; the standar $\$$ error reflects the variations within this group.

CHROMATOGRAPHY

Chromatography showed the material in patient 


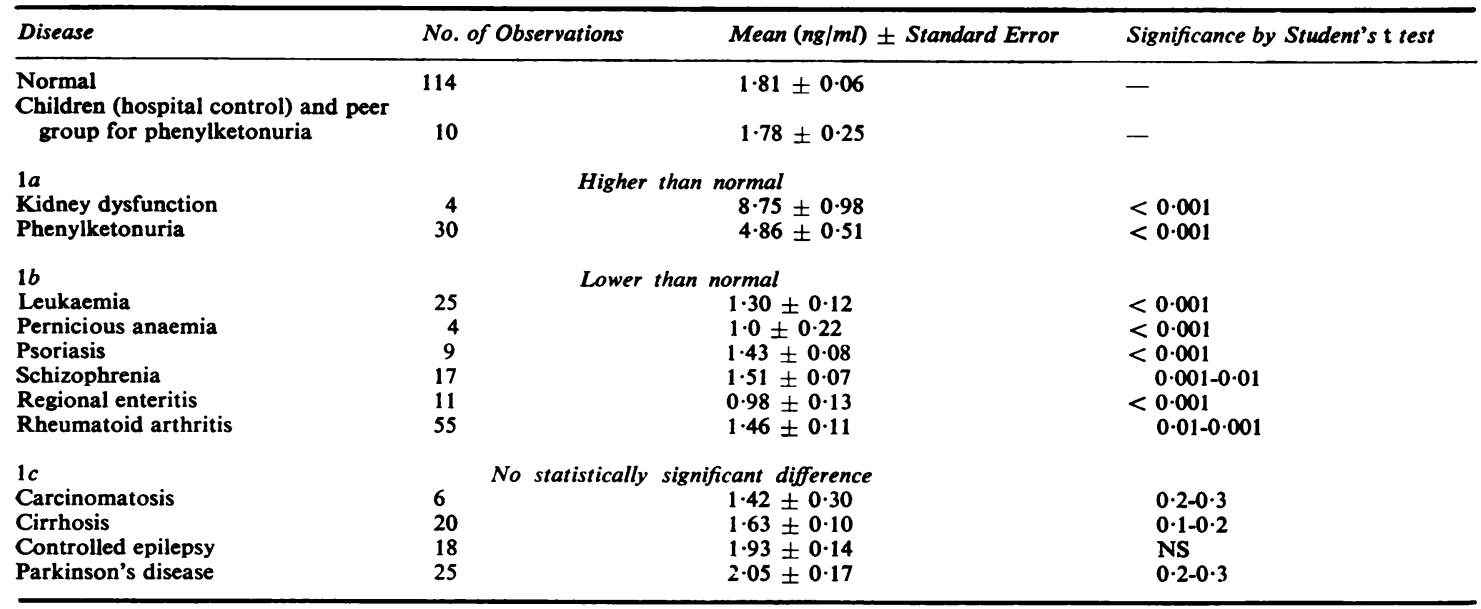

Table I Serum levels of biopterin derivatives in disease and the significance of their variation from normal

\begin{tabular}{llll}
\hline Disease & No. of Observations & Mean $(\mu \mathrm{g} / \mathrm{ml}) \pm$ Standard Error & Significance by Student's t test \\
\hline Normal & 60 & $2 \cdot 1 \pm 0.19$ & Control \\
Rheumatoid arthritis & 17 & $0.75 \pm 0.18$ & $<0.001$ \\
Controlled epilepsy & 16 & $0.41 \pm 0.35$ & $0.05-0.1$ \\
Kidney dysfunction & 4 & $0.077 \pm 0.048$ & $<0.001$ \\
Schizophrenia & 20 & $3 \cdot 55 \pm 1.09$ & $0.1-0.2$
\end{tabular}

Table II Urine levels of biopterin derivatives in disease and the significance of their variation from normal

\begin{tabular}{|c|c|c|c|c|c|c|}
\hline & \multicolumn{2}{|c|}{ White Matter } & \multicolumn{2}{|c|}{ Grey Matter } & \multicolumn{2}{|c|}{ Substantia Nigra } \\
\hline & ng/fresh $g$ & $\frac{\text { Dry } w t}{\text { Fresh } w t} \times 100$ & $n g /$ fresh $g$ & $\frac{\text { Dry wt }}{\text { Fresh wt }} \times 100$ & ng/fresh $\mathbf{g}$ & $\frac{\text { Dry } w t}{\text { Fresh wt }} \times 100$ \\
\hline $\begin{array}{l}\text { Brain } \\
1 \\
2 \\
3 \\
4\end{array}$ & $\begin{array}{r}25 \\
20 \\
112 \\
28\end{array}$ & $\begin{array}{l}\overline{27} \% \\
\overline{-}\end{array}$ & $\begin{array}{l}25 \\
20 \\
22 \\
35\end{array}$ & $\begin{array}{l}\overline{16} \% \\
\overline{17} \%\end{array}$ & $\begin{array}{r}53 \\
500 \\
175 \\
175\end{array}$ & $\begin{array}{l}\overline{11} \% \\
\overline{24} \%\end{array}$ \\
\hline $\begin{array}{l}\text { Liver } \\
1 \\
2 \\
3 \\
4\end{array}$ & $\begin{array}{r}41 \\
100 \\
163 \\
144\end{array}$ & $\begin{array}{l}23 \% \\
27 \% \\
24 \% \\
-\end{array}$ & & & & \\
\hline
\end{tabular}

Table III Biopterin derivatives in human body fluids and tissues

\begin{tabular}{lcc} 
No. of Estimations & & Mean $(\mathrm{ng} / \mathrm{ml}) \pm$ Standard Error of Mean \\
Whole blood & $(10)$ & $4 \cdot 0 \pm 0.18$ \\
Red blood cells & $(10)$ & $7.8 \pm 0 \cdot 55$ \\
CSF & $(19)$ & $1.9 \pm 0 \cdot 13$ \\
Milk & $(6)$ & $131.0 \pm 13.6$ \\
Milk after filtration & $(6)$ & $79.3 \pm 6.3$ \\
\multicolumn{2}{l}{ through Visking tubing } &
\end{tabular}

with kidney disease to be the same as in normal serum (probably 7,8-dihydrobiopterin) although increased in quantity. One patient with untreated myeloma had a very raised level of Crithidia activity $(70 \mathrm{ng} / \mathrm{ml})$, and chromatography exposed a second material which co-chromatographed with biopterin and tetrahydrobiopterin. The urine of epileptics and rheumatoid arthritics showed two peaks identical with those found in normal urine, probably tetrahydrobiopterin and 7,8-dihydrobiopterin (Leeming and Blair, 1974).

Chromatography of brain and liver produced 
two materials, one of which co-chromatographed with 7,8-dihydrobiopterin and the other with 5,6,7,8-tetrahydrobiopterin and biopterin.

FOLATES AND ANTIFOLATES

Table IV details the levels in untreated psoriasis compared with treated psoriasis and other patients on antifolate drugs. Azothioprine did not have any great effect on biopterin derivatives in serum while methotrexate and Septrin caused substantial increases.

Table V shows that oral folates did not affect the serum levels of biopterin derivatives. Methotrexate orally (fig 1) or intravenously (fig 2 ) gave rise to increased serum biopterin derivatives which were sustained for a considerable period of time. In two of the 12 leukaemic children on methotrexate the level was measured at 11 days and 14 days and gave results of $4.8 \mathrm{ng} / \mathrm{ml}$ and $5.6 \mathrm{ng} / \mathrm{ml}$ respectively. Oral 5-methyltetrahydrofolic acid after oral methotrexate did not increase the level of biopterin derivatives in serum but oral folic acid and oral and intravenous 5-formyltetrahydrofolic acid caused a substantial rise (fig 3). Oral biopterin (fig 4) caused a dramatic rise in the serum value which continued after 4 hours.

\section{Discussion}

The levels in normal subjects varied considerably from those of Frank et al (1963), who gave values

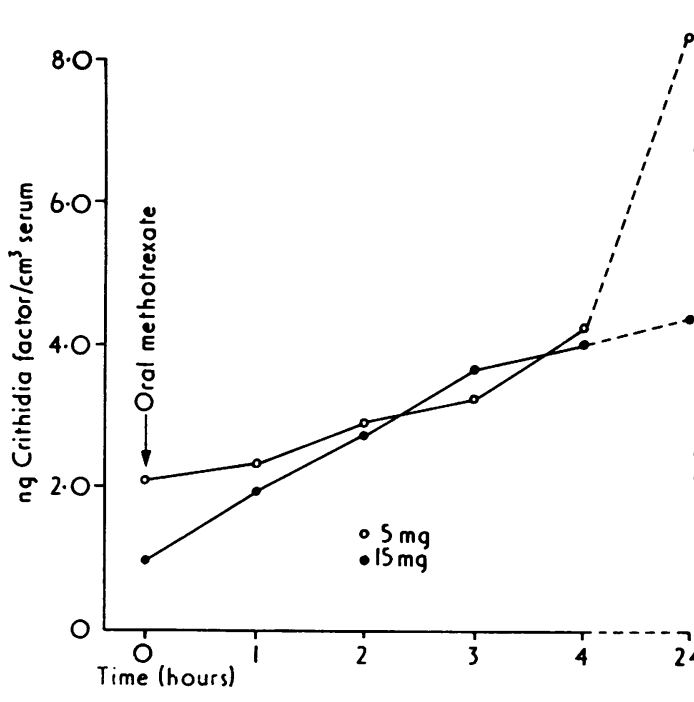

Fig 1 Serum Crithidia factor levels in two patients following oral methotrexate.

of $27 \mathrm{ng} / \mathrm{ml}$ in serum and $48 \mathrm{ng} / \mathrm{ml}$ in whole bloos but were similar in that whole blood gave approx mately twice the serum value. Subsequently, Bake et al (1974) reported plasma and blood levels of $0.9 \mathrm{ng} / \mathrm{ml} \pm 0.2$ and $1.9 \mathrm{ng} / \mathrm{ml} \pm 0.8$ in 31 subject $\vartheta_{5}$ roughly half the values given in this paper. These

\begin{tabular}{|c|c|c|c|c|c|c|}
\hline & Normals & $\begin{array}{l}\text { Untreated } \\
\text { Psoriatics }\end{array}$ & $\begin{array}{l}\text { Psoriatics on } \\
\text { Azothiaprine }\end{array}$ & $\begin{array}{l}\text { Psoriatics on } \\
\text { Methotrexate }\end{array}$ & $\begin{array}{l}\text { Leukaemic } \\
\text { Children on } \\
\text { Methotrexate }\end{array}$ & $\begin{array}{l}\text { Patients on } \\
\text { Septrin }\end{array}$ \\
\hline $\begin{array}{l}\text { No. of samples } \\
\text { Mean serum level } \\
\text { (ng/ml) with } \\
\text { standard error } \\
\text { of mean }\end{array}$ & $\begin{array}{l}114 \\
1.81\end{array} 0.06$ & $\begin{array}{l}9 \\
1.43 \pm 0.08\end{array}$ & $\stackrel{4}{1 \cdot 18} \pm 0 \cdot 23$ & $\begin{array}{l}14 \\
15 \cdot 24 \pm 4 \cdot 94\end{array}$ & $\begin{array}{l}12 \\
4 \cdot 3\end{array} 0 \cdot 31$ & $\begin{array}{l}4 \\
7 \cdot 35\end{array} 2 \cdot 49$ \\
\hline Range (ng/ml) & $0.4-3 \cdot 8$ & $1 \cdot 0-1 \cdot 8$ & $0 \cdot 7 \cdot 1 \cdot 7$ & $3 \cdot 0-60 \cdot 0$ & $2 \cdot 8-5 \cdot 6$ & $1 \cdot 4-13 \cdot 5$ \\
\hline
\end{tabular}

Table IV Biopterin derivative levels in treated and untreated psoriatics compared with other patients on dihydrofolat reductase inhibiting drugs

\begin{tabular}{|c|c|c|c|c|c|c|c|c|}
\hline & $\begin{array}{l}\text { 5-Methyl- } \\
\text { tetrahydro- } \\
\text { folic Acid }\end{array}$ & Folic Acid & Pteroic Acid & $\begin{array}{l}\text { 5-Formyl- } \\
\text { tetrahydro- } \\
\text { folic Acid }\end{array}$ & $\begin{array}{l}\text { I0-Formyl- } \\
\text { folic Acid }\end{array}$ & $\begin{array}{l}\text { 5-Methyl-5,6- } \\
\text { dihydrofolic } \\
\text { Acid }\end{array}$ & $\begin{array}{l}\text { 5-Methyl-5,8- } \\
\text { dihydrofolic } \\
\text { Acid }\end{array}$ & $\begin{array}{l}\text { 7,8-Dihydro- } \\
\text { folic Acid }\end{array}$ \\
\hline $\begin{array}{l}\text { No. of } \\
\text { subjects } \\
\text { Hours }\end{array}$ & 5 & 3 & 2 & 4 & 2 & 5 & 3 & 4 \\
\hline $\begin{array}{l}0 \\
\frac{1}{2} \\
1 \\
1 \frac{1}{2} \\
2 \\
2 \frac{1}{2}\end{array}$ & $\begin{array}{l}2.07 \pm 0.13 \\
1.88 \pm 0.11 \\
1.73 \pm 0.09 \\
1.80 \pm 0.09 \\
1.80 \pm 0.09 \\
-\quad\end{array}$ & $\begin{array}{l}1.17 \pm 0.17 \\
1.23 \pm 0.09 \\
1.27 \pm 0.20 \\
1.30 \pm 0.12 \\
1.38 \pm 0.16\end{array}$ & $\begin{array}{l}1.63 \pm 0.12 \\
1.50 \pm 0.20 \\
1.50 \pm 0.10 \\
1.53 \pm 0.02 \\
1.55 \pm 0.05 \\
-\end{array}$ & $\begin{array}{l}1.63 \pm 0.30 \\
1.70 \pm 0.24 \\
1.43 \pm 0.21 \\
1.20 \pm 0.33 \\
1.25 \pm 0.13 \\
-\end{array}$ & $\begin{array}{l}0.55 \pm 0.05 \\
0.53 \pm 0.17 \\
0.58 \pm 0.22 \\
0.50 \pm 0.30 \\
0.68 \pm 0.02 \\
-\end{array}$ & $\begin{array}{l}2.36 \pm 0.62 \\
2.42 \pm 0.55 \\
2.28 \pm 0.53 \\
2.24 \pm 0.57 \\
1.94 \pm 0.36\end{array}$ & $\begin{array}{l}1.20 \pm 0.23 \\
1.30 \pm 0.26 \\
1.33 \pm 0.35 \\
1.17 \pm 0.37 \\
1.53 \pm 0.32 \\
-\end{array}$ & $\begin{array}{l}2.15 \pm 0.48 \\
1.90 \pm 0.26 \\
1.78 \pm 0.24 \\
1.83 \pm 0.24 \\
1.78 \pm 0.22 \\
-\end{array}$ \\
\hline 3 & $1.85 \pm 0.15$ & $1 \cdot 30 \pm 0.09$ & $1.65 \pm 0.45$ & $1 \cdot 18 \pm 0 \cdot 28$ & $0.80 \pm 0$ & $1.96 \pm 0.36$ & $1.30 \pm 0.35$ & $1.93 \pm 0.23$ \\
\hline
\end{tabular}

Table V Biopterin derivative levels $(\mathrm{ng} / \mathrm{ml})$ in serum following oral folates in normal fasting adults 


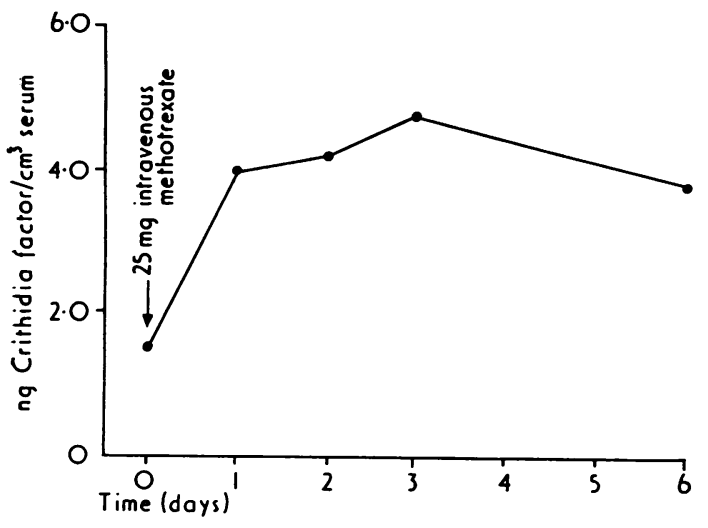

Fig 2 Serum Crithidia factor levels over six days in a patient following intravenous methotrexate.

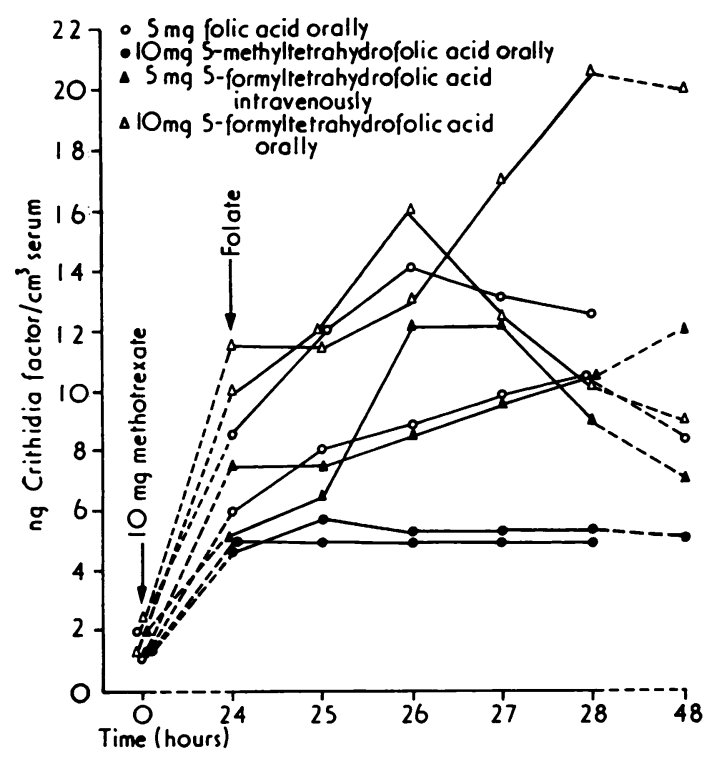

Fig 3 Serum Crithidia factor levels when folates were given 24 hours after $10 \mathrm{mg}$ methotrexate.

same workers gave values for CSF which were considerably lower than those presented here$0.4 \mathrm{ng} / \mathrm{ml} \pm 0.21$ as opposed to our $1.9 \mathrm{ng} / \mathrm{ml} \pm 0.13$. These differences could reflect different techniques; in our hands, recovery of added biopterin and tetrahydrobiopterin was very close to $100 \%$ over a range of concentrations.

Urinary excretion was found to be approximately $1.6 \mathrm{mg} /$ day compared to the findings of Baker et al (1974) $-2 \cdot 1 \mathrm{mg} /$ day and Fukushima and Shiota (1972) $-1.4 \mathrm{mg} /$ day.

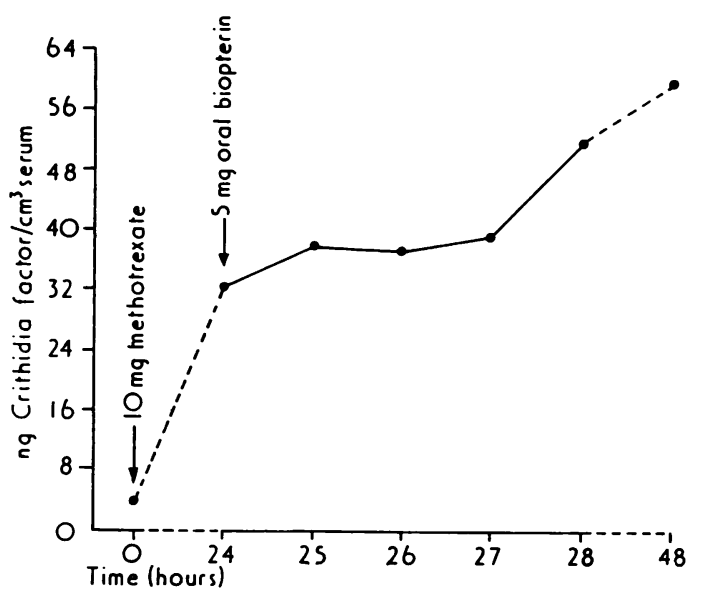

Fig 4 Serum Crithidia factor levels when biopterin was given 24 hours after $10 \mathrm{mg}$ methotrexate.

The levels of biopterin derivatives found in the serum and urine of patients in a number of diseased conditions (table I) could provide clues to the metabolism of these materials. The very high levels found in the serum of patients with kidney disease and the concurrently low level found in urine suggest that the kidney plays a vital role in maintaining serum levels within narrow limits. The raised levels in phenylketonuria can be correlated with amino acid levels and will be presented separately (Leeming et al, 1976). The disorders with abnormal cellular proliferation all showed low serum levels. The depressed levels in the serum of schizophrenics are difficult to explain. The cirrhotics did not have significantly different levels from normals in contrast to the findings of Baker et al (1974) who found raised levels in patients with alcoholic liver disease, which they assumed to reflect impairment of biopterin catabolism accompanied by a lesser impairment in biopterin synthesis. In Parkinson's disease the mean serum level was slightly above normal but not significantly so $(P=0 \cdot 2-0 \cdot 3)$. However, only one patient was certainly unmedicated and had a raised level $(5 \cdot 2 \mathrm{ng} / \mathrm{ml})$. Any change at tissue level may not necessarily be reflected in serum concentrations of biopterin derivatives if the blood/brain barrier is intact. In rats, tetrahydrobiopterin has difficulty in penetrating in the opposite direction (Kettler et al, 1974).

That three of the four myelomatous patients had significantly lower serum levels than normal was in agreement with findings in the other malignant diseases. However, one patient had a very raised level $(70 \mathrm{ng} / \mathrm{ml})$ in plasma taken off for replacement with 
protein-free substrate before maintenance on cytotoxic drugs. Protein binders for folates are currently of interest to haematologists (Waxman, 1975) and nutritionists (Ford, 1974) alike, and the possibility exists that there is a protein which binds biopterin or its derivatives, and in this patient it was stimulated to overproduction. Chromatography of serum from this patient in the three solvent systems showed a considerable quantity of the normally undetectable (in serum) component of Crithidia factor which cochromatographed with biopterin and tetrahydrobiopterin. The other material normally found in serum and previously described as 7,8-dihydrobiopterin was also raised.

As the Crithidia assay showed a low level of growth in the absence of added biopterin, any inhibitory substance would have been detected during the chromatography. Therefore inhibition can be ruled out as a contributory factor to low levels in specimens where chromatography was employed.

The lack of response to oral folates (table V) demonstrates that in normal circumstances these compounds do not contribute to the synthesis of biopterin derivatives. Concurrent measurement of folates showed normal absorption. Folates are readily absorbed (Ratanasthien et al, 1974) with the exception of pteroic acid (Brown et al, 1973; Blair et al, 1974). Fukushima and Shiota (1972) found that oral folic acid did not raise the level of biopterin derivatives in urine.

The raised levels of biopterin derivatives following folate antagonists (figs 1 and 2) could be caused by minor pathways to biosynthesis being fed by unmetabolized folate; or unreduced biopterin derivatives, accumulated by inhibition of reduction back to the tetrahydro forms, may be the trigger for increased synthesis of reduced forms. Biopterin, when given to a patient on methotrexate (fig 4), led to a very raised level in the serum, much above the levels following oral biopterin in unmedicated subjects (Leeming, 1975). This may have been due in part to renal dysfunction (blood urea $9.1 \mathrm{mmol} / \mathrm{l}$ ), which could have accounted for the raised level $(4.0 \mathrm{ng} / \mathrm{ml})$ before methotrexate was given (Baker et al, 1974). Chromatography of serum from this patient 24 hours after biopterin was given showed a raised level of 7,8-dihydrobiopterin as well as a substantial amount of tetrahydrobiopterin and/or biopterin.

The rises in serum levels following oral folic acid and both oral and intravenous 5-formyltetrahydrofolic acid in patients on methotrexate (fig 3) contrasted with the failure in response to oral 5-methyltetrahydrofolic acid. The increases demonstrated between 3 and 4 hours occurred after the normal peak serum folate level following oral folates
(Ratanasthein et al, 1974). This may suggest that i the presence of methotrexate these compounds con tribute to serum biopterin derivatives by thei metabolism either providing a substrate for bioe synthesis or stimulating synthesis from anothe starting point.

Very little is known about the metabolism of biopterin derivatives in man except for their specific role in the enzymatic hydroxylation of phenylalanines tyrosine, and tryptophan. The work in rats suggest? an endogenous source (Pabst and Rembold, 1966 and non-passage of the blood brain barrier (Kettleo et al, 1974), which, in the context of the variable levels in brain and liver presented here, point t\& widely dispersed synthesis dependent on demand A defect in the reduction of tetrahydrobiopterik has been suggested as a cause of dietary resistan $\overline{\$}$ phenylketonuria (Smith et al, 1975). Faulty biog synthesis could have a similar effect which would be distinctive following assay and identification of biopterin derivatives.

\section{References}

Baker, H., Frank, O., Bacchi, C. J., and Hutner, S. $\dot{H}^{\circ}$ (1974). Biopterin content of human and rat fluids and tissues determined protozoologically. Amer. J. clin. Nutrs 27, 1247-1253.

Baker, H., Frank, O., Pasher, I., Sobotka, H., and Hutneథ्मे S. H. (1961). Vitamin-levels in blood and serum. Natur (Lond.), 191, 78.

Blair, J. A., Pearson, A. J., and Robb, A. J. (1975). Auto oxidation of 5-methyl-5,6,7,8-tetrahydrofolic acid.J. chen Soc. [Perkin II].

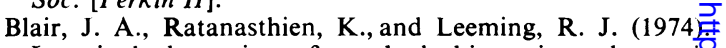
Intestinai absorption of tetrahydrobiopterin and pteroic. acid in man: a comparison of models for the transport क्ष folate across the small intestine. (Abstr.) Gut, 15, 832.

Blair, J. A. and Saunders, K. J. (1970). A convenient metho for the preparation of dl-5-methyltetrahydrofolic aci (dl-5-methyl-5,6,7,8-tetrahydropteroyl-L-monoglutamis acid). Analyt. Biochem., 34, 376-381.

Blakley, R. L. (1959). The reaction of tetrahydropteroyk glutamic acid and related hydropteridines with forma오 dehyde. Biochem. J., 72, 707-715.

Brown, J. P., Scott, J. M., Foster, F. G., and Weir, D. G (1973). Ingestion and absorption of naturally occurring: pteroylmonoglutamates (folates) in man. Gastroenterolog, 요 64, 223-232.

Ford, J. E. (1974). Some observations on the possible nutro tional significance of vitamin $\mathrm{B}_{12}$ and folate-binding proteins in milk. Brit. J. Nutr., 31, 243-257.

Frank, O., Baker, H., and Sobotka, H. (1963). Blood- an $\mathbb{7}$ serum-levels of water-soluble vitamins in man and animales Nature (Lond.), 197, 490-491.

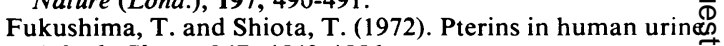
J. biol. Chem., 247, 4549-4556.

Futterman, S. (1963). In Methods in Enzymology, edited b S. P. Colowick and N. O. Kaplan, Vol. VI, p. 18. Academi? Press, New York.

Gapski, G. P., Whiteley, J. M., and Huennekens, F. M. (1971 $\frac{\Omega}{D}$ Hydroxylated derivatives of 5-methyl-5,6,7,8-tetrahydro folate. Biochemistry, 10, 2930-2934.

Guttman, H. N. and Wallace, F. G. (1964). Nutrition and physiology of the Trypanosomatidae. In Biochemist 
and Physiology of Protozoa, Vol. III, edited by S. H. Hutner, p. 459. Academic Press, New York.

Hosoda, S. and Glick, D. (1966). Studies in histochemistry. LXXIX. Properties of tryptophan hydroxylase from neoplastic murine mast cells. J. biol. Chem., 241, 192-196.

Iwai, K., Kobashi, M., and Fujisawa, H. (1970). Occurrence of Crithidia factors and folic acid in various bacteria. J. Bact., 104, 197-201.

Kaufman, S. (1963). The structure of the phenylalaninehydroxylation cofactor. Proc. Nat. Acad. Sci. (Wash.), 50, 1085-1093.

Kettler, R., Bartholini, G., and Pletscher, A. (1974). In vivo enhancement of tyrosine hydroxylation in rat striatum by tetrahydrobiopterin. Nature (Lond.), 249, 476-478.

Leeming, R. J. (1975). Studies in the handling and absorption of biopterin derivatives in man. M.Ph. Thesis, University of Aston, Birmingham.

Leeming, R. J. and Blair, J. A. (1974). Crithidia factors in human urine. Biochem. Med., 11, 122-128.

Leeming, R. J., Blair, J. A., Green, A., and Raine, D. N. (1976). (In preparation).
Leeming, R. J. and Graham, H. P. (1973). An automated method for microbiological assays. Med. Lab. Technol., 30, 21-25.

Levitt, M., Spector, S., Sjoerdsma, A., and Udenfriend, S. (1965). Elucidation of the rate-limiting step in norepinephrine biosynthesis in perfused guinea-pig heart. J. Pharmacol. exp. Ther., 148, 1-8.

Pabst, W. and Rembold, H. (1966). Über das Verhalten des Biopterins im Säugetierorganismus. II. Einfluss von Vitaminmangel und eines Antagonisten auf die Biopterinausscheidung und das Wachstum der Ratte. Hoppe-Seylers $Z$. physiol. Chem., 344, 107-112.

Ratanasthien, K., Blair, J. A., Leeming, R. J., Cooke, W. T., and Melikian, V. (1974). Folates in human serum. J. clin. Path., 27, 875-879.

Smith, I., Clayton, B. E., and Wolff, O. H. (1975). New variant of phenylketonuria with progressive neurological illness unresponsive to phenylalanine restriction. Lancet, 1, 1108-1111.

Waxman, S. (1975). Folate binding proteins. Brit. J. Haemat., 29, 23-29. 